\title{
Rancang Bangun Aplikasi Word Game Scramble untuk Pengenalan Budaya Minahasa
}

\author{
Ricky Iferdy Mamahit ${ }^{1)}$, Virginia Tulenan ${ }^{2)}$, Sary Paturusi ${ }^{3)}$ \\ 1,2,3 Teknik Informatika Universitas Sam Ratulangi Manado, Indonesia. \\ Email : 120216003@student.unsrat.ac.id ${ }^{1)}$,virginia.tulenan@gmail.com ${ }^{2)}$, sarypaturusi@gmail.com ${ }^{3)}$
}

\begin{abstract}
Abstrak - Minahasa adalah suatu suku bangsa yang mendiami suatu daerah pada bagian timur laut jazirah Sulawesi Utara . Minahasa memiliki banyak budaya yang kita kenal disekitar kita, mulai dari seni tari, seni musik, peninggalan budaya, obyek pariwisata dan masih banyak lagi. Seiring dengan perkembangan zaman, kebudayaan yang ada di Indonesia pada saat ini secara perlahan tapi pasti mulai terlupakan, Hal ini terjadi karena begitu banyak kebudayaan asing yang masuk dan dengan mudah diterima oleh masyarakat, Terutama banyak diantaranya anak anak dan kaum muda lebih menyukai budaya asing dari pada budaya tanah air.

Dengan Merancang dan Membangun Aplikasi Word Game Scramble untuk Pengenalan Budaya Minahasa dapat menjadi sarana pengenalan budaya minahasa yang menarik dan bermanfaat bagi masyarakat .Penulis menggunakan Unity $3 D$ dalam membuat Aplikasi Word Game Scramble untuk Pengenalan Budaya Minahasa. Dalam Pembuatan Aplikasi metode yang digunakan adalah Metode Extream Programing. Dalam Aplikasi ini dibuat meliputi Budaya Minahasa tentang Marga Minahasa, Arti Nama Desa, Peninggalan Budaya Seni Tari dan Seni Musik Minahasa. Aplikasi Word Game Scramble Pengenalan Budaya Minahasa menjadi sarana untuk memperkenalkan masyarakat dengan cara yang interaktif dan menarik.
\end{abstract}

Kata kunci: Minahasa ,Game, Unity 3D, Word Scramble

\section{PENDAHULUAN}

Bangsa Indonesia adalah bangsa yang kaya akan suku-suku dengan budayanya masing-masing. Budaya atau kebudayaan diartikan sebagai suatu cara hidup yang berkembang dan dimiliki bersama oleh sebuah kelompok orang dan diwariskan dari generasi ke generasi. Budaya terbentuk dari beberapa unsur diantaranya sistem agama dan politik, adat istiadat, bahasa, perkakas, pakaian, bangunan, dan karya seni. Budaya juga merupakan satu unsur penting sebagai ciri khas dan identitas dalam suatu negara. Sebagai anak-anak bangsa, kita perlu mengetahui dan mengenal setiap suku dan budaya yang ada. Salah satu suku di Indonesia adalah suku Minahasa yang ada di pulau Sulawesi Utara. Minahasa memiliki banyak budaya yang kita kenal disekitar kita, mulai dari seni tari, seni musik, peninggalan budaya, obyek pariwisata dan masih banyak lagi.

Seiring dengan perkembangan zaman, kebudayaan yang ada di Indonesia pada saat ini secara perlahan tapi pasti mulai terlupakan, Hal ini terjadi karena begitu banyak kebudayaan asing yang masuk dan dengan mudah diterima oleh masyarakat, Terutama banyak diantaranya anak anak dan kaum muda lebih menyukai budaya asing dari pada budaya tanah air. Padahal ada banyak sekali Pengetahuan tentang kebudayaan terutama budaya Minahasa yang dapat kita pelajari dan perkenalkan kepada masyarakat diberbagai kalangan usia. Perkembangan teknologi adalah salah satu faktor yang berperan dalam membawa aspek baru dalam berbagai aspek kehidupan. Dengan adanya teknologi yang berkembang saat ini, dapat kita gunakan sebagai media untuk memperkenalkan Budaya yang ada di indonesia terutama Budaya Minahasa.

Dari masalah di atas, maka penulis mempuyai ide untuk membuat Aplikasi Word Game Scramble sebagai media Pengenalan Budaya Minahasa agar Budaya Minahasa dapat dipelajari dan perkenalkan kepada masyarakat.

\section{LANDASAN TEORI}

\section{A. Multimedia}

Multimedia adalah kombinasi dari elemen teks, gambar, suara, animasi, dan video yang dimanipulasi secara digital. multimedia akan menjadi multimedia interaktif ketika pengguna diberikan kontrol terhadap informasi apa yang ditampilkan dan kapan informasi itu ditampilkan ${ }^{[12]}$.

\section{B. Game}

Game adalah salah satu jenis aktifitas bermain, yang didalamnya dilakukan dalam konteks berpura - pura namun terlihat seperti realitas, di mana pemain mencoba untuk mencapai satu kemenangan dan dilakukan sesuai dengan aturan permainan yang dibuat ${ }^{[3]}$.

\section{Word Game Scramble}

Word Game Scramble artinya adalah permainan Acak Kata. Menurut Microsoft dalam Gamenya Acak Kata adalah game kata yang menantang di mana Anda harus menempatkan semua huruf kembali sesuai dengan urutan yang benar. Kata-kata disajikan kepada Anda dalam bentuk blok bangunan yang diacak dan tujuan Anda adalah mengganti susunan huruf yang diacak tersebut untuk menemukan kata-kata yang benar. 


\section{E-Journal Teknik Informatika Vol 11, No.1 (2017) ISSN : 2301-8364}

\section{Minahasa}

Minahasa berasal dari kata MINAESA yang berarti PERSATUAN, pada Zaman dahulu minahasa dikenal dengan nama Malesung. Asal usul orang minahasa berdasarkan Penyelidikan dan penelitian ahli bangsa yang berasal dari Eropa bahwa orang minahasa berasal dari utara dan mempunyai pertalian serta banyak kesamaan dengan bangsa Philipina dan Jepang, baik dalm bentuk tubuh fisik, maupun keadaan rambut, tulang, paras, bentuk mata dan lain lain ${ }^{[2]}$

\section{E. Arti Marga Minahasa}

Nama keluarga yang telah digunakan sebagai nama keturunan bagi orang Minahasa atau lebih dikenal dengan istilah FAM, diambil dari nama keluarga yang digunakan oleh kepala rumah tangga (orang tua lelaki). Setiap anak yang lahir dalam perkawinan yang sah, otomatis disamping nama depannya, melekat pula nama keturunan keluarga dari sang Bapak. Khusus bagi seorang wanita yang telah kawin maka nama keluarga sang suami langsung disisipkan diantara nama depan dengan nama keturunan keluarga sang wanita tersebut. $\left[{ }^{2}\right]$.

\section{F. Peninggalan Budaya}

Objek-objek Peninggalan Budaya yang ada di Minahasa yaitu, sebagai beikut:

\section{a. Batu Pinawentengan}

Batu Pinabentengan adalah salah satu dari banyaknya Peninggalan Budaya yang ada di tanah Minahasa ini. Kompleks Watu Pinawetengan terletak di desa suatu tempat yang dianggap Keramat dan memiliki Nilai sejarah bagi perkembangan orang minahasa, dari tempat inilah mulai abad ke VII menyebar orang orang minahasa keseluruh penjuru tanah minahasa, Batu bertulis yang terdapat dalam kompleks dapat disaksikan Tulisan tangan dari Dotu Dotu Minahasa pada abad ke VII ${ }^{[2]}$

\section{b. Waruga}

Waruga adalah makam tradisional leluhur suku Minahasa yang terbuat dari 144 jenis batu alam yang terletak di Desa Sawangan. Bentuk makamnya adalah persegi empat dengan lubang ditengah sebelah atas yang ditutup dengan cungkup prisma. Batu makam ini diukir dengan berbagai motif yang menandakan pekerjaan dan jenis kelamin dari manusia yang dikubur didalamnya.

\section{c. Lesung Batu}

Lesung batu kebanyakan ditemukan di Minahasa bagian selatan. Benda ini terbuat dari batu tunggal (monolith), dalam beberapa macam bentuknya. Salah satu lesung batu dari Minahasa yang menarik adalah yang menyerupai dandang (wadah untuk menanak nasi), yaitu memiliki bentuk badan tinggi dan cekung dengan ukuran tinggi $55 \mathrm{~cm}$, diameter bagian dasar $50 \mathrm{~cm}$, diameter badan (bagian cekungan) $40 \mathrm{~cm}$, diameter tepian $60 \mathrm{~cm}$, diameter mulut lubang $20 \mathrm{~cm}$, dan kedalaman lubang $30 \mathrm{~cm}$. Lesung batu kebanyakan ditemukan di daerah Minahasa bagian selatan yaitu di Desa Karimbow, Ranaan Baru, Pontak, Poopo, Motoling, Tonday, megalithuan Baru, Mopolo, Malola, dan Ranaan Lama di Kecamatan Motoling ${ }^{[2]}$ d. Monumen Opo Tololiu

Patung Opo Dotu Tololiu Tua terletak di pertigaan jalan di wilayah Kelurahan Matani Tiga Tomohon Tengah Tomohon. Patung Opo Dotu Tololiu Tua yang terletak di pertigaan pun terlihat, dengan tombak di tangan kiri dan pedang di tangan kanan, tidak lama setelah kami melewati para penari Kabasaran itu. Di bawah Patung Opo Dotu Tololiu Tua itu ada inskripsi yang berbunyi "Tonaas Rarangkang Pakasaan Tombulu Ma Esa-esaan Wo Ma LeoLeo san se Tou Minaesa Wo Rondoren Un Banua. Pakatuan Wo Pakalawiren" yang diresmikan pada tahun 1974 oleh J.F. Lumentut ${ }^{[2] .}$

e. Monumen Korengkeng Sarapung

Patung Korengkeng Sarapung berada di sebuah pertigaan di ujung Boulevard Tondano, Desa Roong, Kecamatan Tondano, Kabupaten Minahasa, Sulawesi Utara. Patung Korengkeng Sarapung dibangun untuk mengenang perjuangan heroik Serapung dan Korengkeng sebagai pemimpin rakyat Minahasa dalam perang Tondano yang terjadi di tahun 1808-1809. Serapung adalah Kapala Walak (pemimpin masyarakat secabang keturunan) Tondano Touliang sedangkan Korengkeng adalah Kapala Walak Tondano Toulimambot dalam pertempuran untuk mempertahankan Tondano dari serbuan tentara kolonial Belanda. Patung Sarapung dan Korengkeng ini menjadi simbol kisah kepahlawan masyarakat Tondano ${ }^{[2] .}$

\section{G. Adobe Illustrator}

Adobe Illustrator merupakan aplikasi untuk mengolah serta mengedit desain atau gambar vektor, dimana aplikasi ini dikembangkan dan dipasarkan oleh Adobe Systems. Adobe Illustrator tersedia di komputer, yang berarti aplikasi ini tidak bisa digunakan di perangkat lain seperti handphone, tablet, dan perangkat lainnya. Adobe Illustrator pertama kali dikembangkan untuk komputer Apple Macintosh pada Desember 1986 dan dirilis pada Januari 1987. Pada waktu itu Adobe Illustrator adalah produk pendamping dari Adobe Photoshop.

\section{H. Unity}

Unity adalah sebuah game engine yang memungkinkan pengguna, baik perorangan maupun tim, untuk membuat sebuah game yang dapat digunakan secara gratis. Unity merupakan sebuah engine multiplatform yang memungkinkan game yang di bangun dapat di-publish untuk berbagai platform. Penggunaan engine versi free dibatasi dengan beberapa fitur yang dikurangi atau bonus modul prefab tertentu yang ditiadakan dan hanya tersedia untuk pengguna berbayar.

Unity Engine dapat mengolah beberapa data seperti objek tiga dimensi, suara, teksture, dan lain sebagainya. Unity Engine memiliki kerangka kerja (framework) lengkap untuk pengembangan profesional. Sistem inti engine ini menggunakan beberapa pilihan bahasa pemrogramam, diantaranya $\mathrm{C} \#$, javascript maupun boo. 


\section{E-Journal Teknik Informatika Vol 11, No.1 (2017) ISSN : 2301-8364}

\section{Extreme Programing}

Pemrograman Ekstrem merupakan salah satu pendekatan pada pengembangan cepat perangkat lunak. Pemrograman Ekstrem menggunakan suatu pendekatan berorientasi obyek sebagai paradigma pengembangan yang diinginkan dan mencakup di dalamnya seperangkat aturan dan praktik-praktik yang terjadi dalam konteks empat kegiatan kerangka kerja: perencanaan, perancangan, pengkodean, dan pengujian. Gambar 2.5 mengilustrasikan proses XP dan menunjukan beberapa ide dan tugas kunci yang terkait dengan setiap aktivitas kerangka kerja.

\section{METODOLOGI PENELITIAN}

\section{A. Metodologi Penelitian}

Pembuatan game pengenalan objek wisata Kota Tomohon ini menggunakan metode Extream Programing.

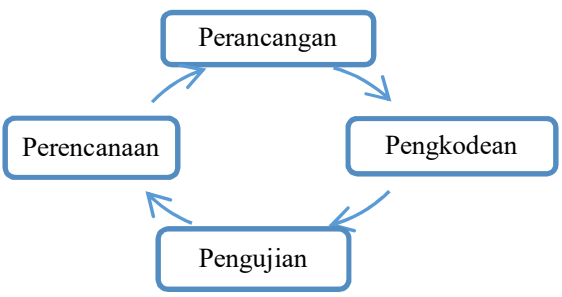

Gambar 1. Metode Extream Programing

Pada tahap Perencanaan, biasanya dimulai dengan merencanakan tujuan, kebutuhan dan gambaran secara umum. Pengumpulan data juga dilakukan pada tahap ini, adapun langkah-langkah yang dilakukan untuk pengumpulan data adalah dengan melakukan studi literatur tentang hal-hal yang berhubungan dengan game yang akan dibuat, yang nantinya dapat mendukung kelengkapan informasi yang dibutuhkan. Kemudian melakukan observasi.

Pada tahap Perancangan, dilakukan Perancangan pembuatan desain secara umum serta konsep terhadap aplikasi yang akan dibuat. Tahap ini melibatkan pembuatan Storyboard, membuat perancangan UML, membuat desain gambar yang akan digunakan dalam aplikasi. Setelah tahap perancangan Pada tahap ini akan dilakukan pengkodean dari konsep yang telah dibuat dalam tahap perancangan. Pembuatan Aplikasi atau Pengkodean dilakukan dengan menggunakan Unity. Uji kelayakan XP, sering juga disebut uji pelanggan, dirinci oleh para pelanggan dan pada dasarnya berfokus pada fitur-fitur dan fungsionalitas sistem/perangkat lunak secara keseluruhan yang dapat terlihat dan ditinjau kembali oleh para pelanggan. Uji kelayakan berasal dari cerita pengguna (user stories) yang telah diimplementasikan sebagai bagian dari suatu rilis perangkat lunak.

\section{B. Metode Pengumpulan Data}

Metode pengumpulan data yang dilakukan penulis dalam penelitian tugas akhir ini yaitu sebagai berikut :
1. Studi Literatur

Studi literature yaitu pengumpulan data-data yang berhubungan dengan tugas akhir yang akan dibuat. Datadata tersebut diperoleh dari buku, internet maupun karya ilmiah.

\section{Observasi}

Pengumpulan data dengan melakukan penelitian langsung di Balai Pelestarian Nilai Budaya (BPNB) Manado.

3. Kuisioner

Pengumpulan data dengan cara memberikan beberapa pertanyaan kepada responden mengenai aplikasi yang dibuat.

\section{Spesifikasi Aplikasi}

1. Informasi Umum

Game yang dibuat yaitu sebuah game yang bertujuan untuk memperkenalkan Budaya yang ada di Minahasa. Di dalam permainan ini, Pemain akan memilih kategori yang akan dimainkan, setiap kategori Objek kata akan di acak dan harus disusun kembali menjadi sebuah kata yang benar, setelah itu pemain akan mendapatkan penjelasan tentang Budaya Minahasa.

2. Genre game

Genre yang dipakai adalah puzzle game, dimana terdapat dua jenis puzzle yang digunakan yaitu memory game dan join game, yang akan pemain mainkan, sehingga pemain dapat melihat informasi dari objek wisata tersebut.

\section{Target pemain}

Aplikasi Word Game Scramble Untuk Pengenalan Budaya Minahasa yang akan dibuat ditargetkan untuk semua kalangan.

\section{Keunikan game}

Keunikan dari game ini yaitu sebagai media untuk memperkenalkan Budaya Minahasa dimana User akan menyusun sebuat kata acak dan dalam kata itu terdapat sebuah arti dalam budaya minahasa. Penggunaannya sangat mudah dimengerti, bersifat edukasi, dan dapat memberikan informasi tentang Budaya Minahasa.

5. Target Hardware

Game ini ditujukan kepada pemain yang memiliki Smartphone Berbasis Android.

6. Teknologi yang digunakan

a. Bahasa pemrograman : C\#

b. Game engine : Unity3D 5.5

c. Sistem operasi : Window 10 Pro Versi 1607

d. Spesifikasi computer yang digunakan :

- Processor : Intel(R) Core(TM) i3-3217U $1.8 \mathrm{GHz}$

- VGA Card : Intel HD Graphics 4000

- VGA Card Diskrit : AMD Radeon R5 M240

- RAM : 4 GB

- Hard Disk : 500 GB 
7. Gameplay

Pada awal permainan, pemain akan masuk ke menu game. Dalam menu game terdapat tombol mulai, tentang minahasa, Tutorial Permainan, tentang aplikasi dan keluar. Pada tombol Mulai di sediakan empat kategori permainan. Kemudian pemain akan memilih Kategori yang ingin dimainkan. Setelah pemain menyelesaikan permainan, pemain akan mendapatkan penjelasan budaya minahasa. Apabila pemain tidak bisa menyelesaikan kata yang di acak dengan waktu yang telah ditentukan pemain akan secara otomatis pindah ke Scene kata acak berikutnya. Pada Scene hasil terdapat bintang dan Nilai yang telah pemain dapatkan dalam menyelesaikan kata dan juga tombol untuk kembali ke menu game dan tombol untuk keluar dari game.

Pada Word Game Scramble Untuk Pengenalan Budaya Minahasa terdapat 4 Kategori yang akan dimainkan, diantaranya ;

a. Arti Marga Minahasa

b. Peninggalan Budaya

c. Seni Musik \& Seni Tari

d. Arti Nama Desa

D. Perancangan Aplikasi

1. Storyboard

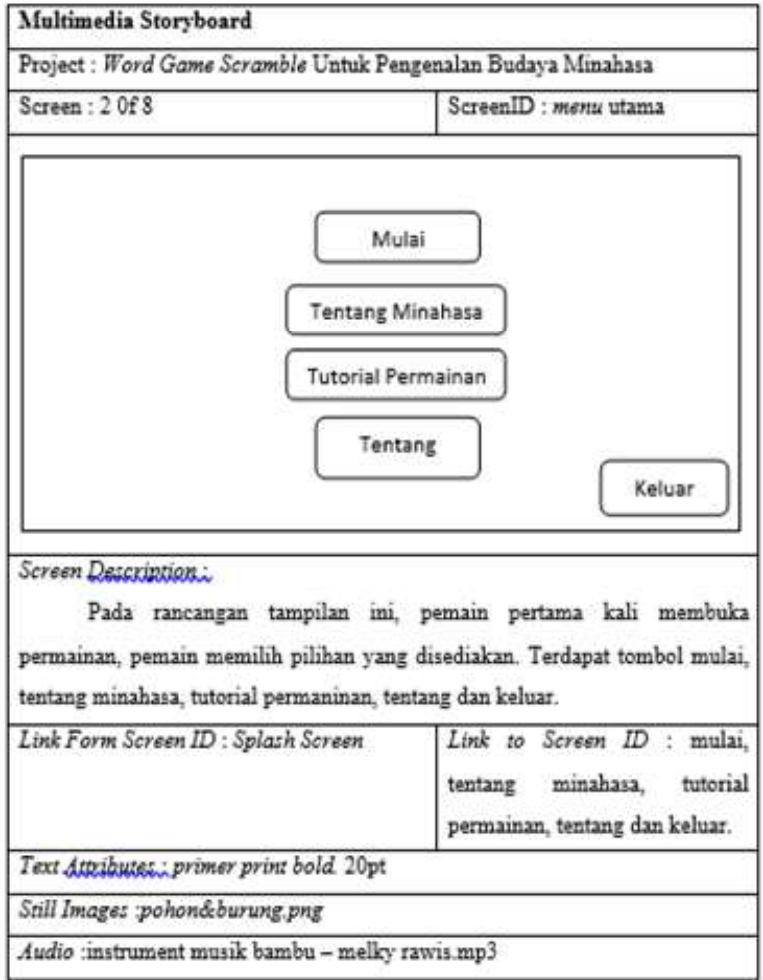

Gambar 2. Storyboard Game
2. Diagram UML

\section{a. Use Case Diagram}

Use case diagram menggambarkan fungsionalitas yang diharapkan dari sebuah sistem. Sebuah use case merepresentasikan sebuah interaksi antara aktor dengan sistem.

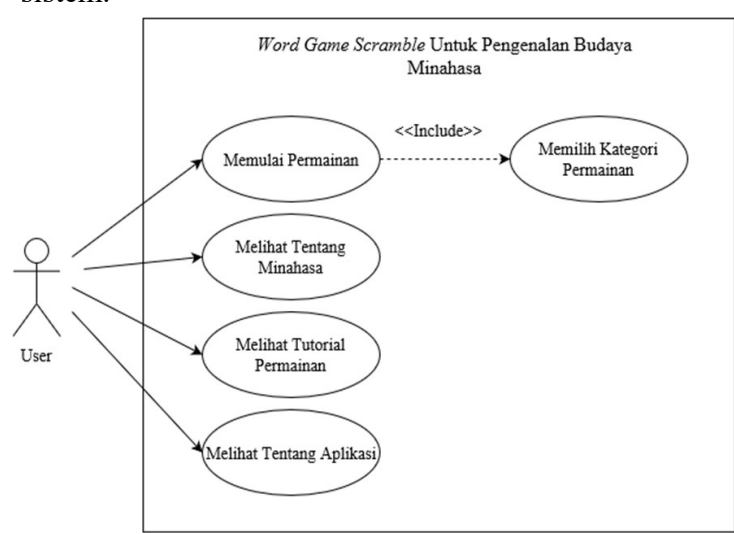

Gambar 3. Use Case Main Menu

\section{b.Activity Diagram}

Acivity diagram menggambarkan berbagai alur kegiatan secara umum yang ada didalam game. Activity diagram ini dibagi menjadi tiga diagram, yang pertama diagram Scene Memulai Permainan.

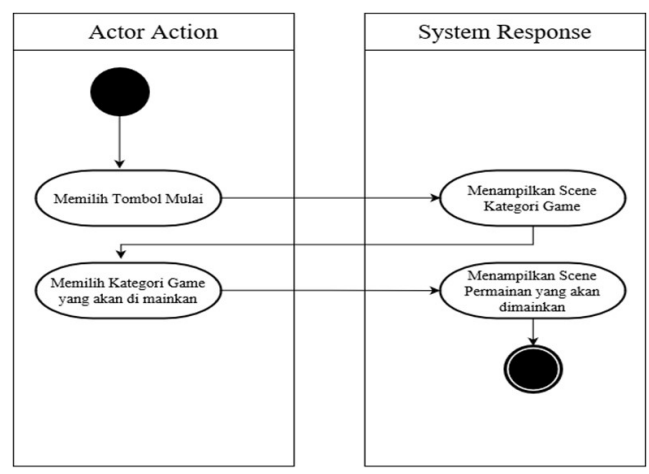

Gambar 4. Activity Diagram Mulai Permainan

\section{HASIL DAN PEMBAHASAN}

A. Implementasi Antar Muka

Penelitian dengan judul "Word Game Scramble Untuk Pengenalan Budaya Minahasa" sudah melewati proses pembuatan dan telah selesai dibuat. Berikut adalah Spesifikasi Aplikasi :

Nama Aplikasi : Word Game Scramble Of Minahasa

Persyaratan Sistem Minimal :

a). OS: Android 4.1 Jelly Bean atau lebih tinggi 
E-Journal Teknik Informatika Vol 11, No.1 (2017) ISSN : 2301-8364

b) RAM : $512 \mathrm{MB}$ atau lebih tinggi

c) Resolusi Layar : 720 x 1280 pixels

Ukuran Aplikasi : $32 \mathrm{MB}$

\section{Splash Screen}

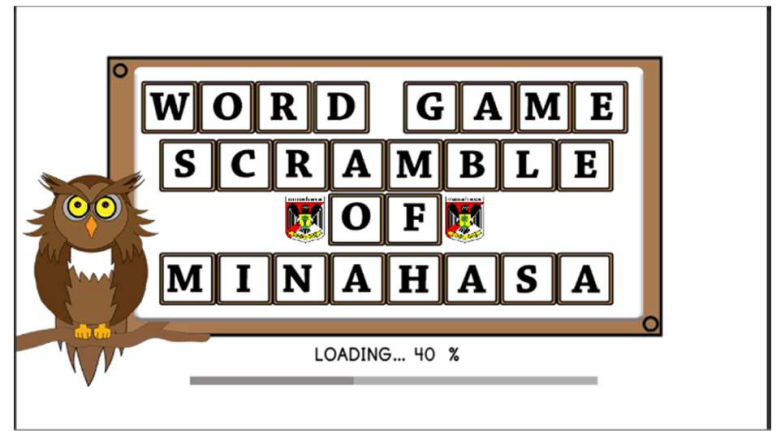

Gambar 5. Splash Screen

Splash Screen tampilan awal saat user membuka aplikasi Word Game Scramble untuk pengenalan Budaya Minahasa.

\section{Menu Utama}

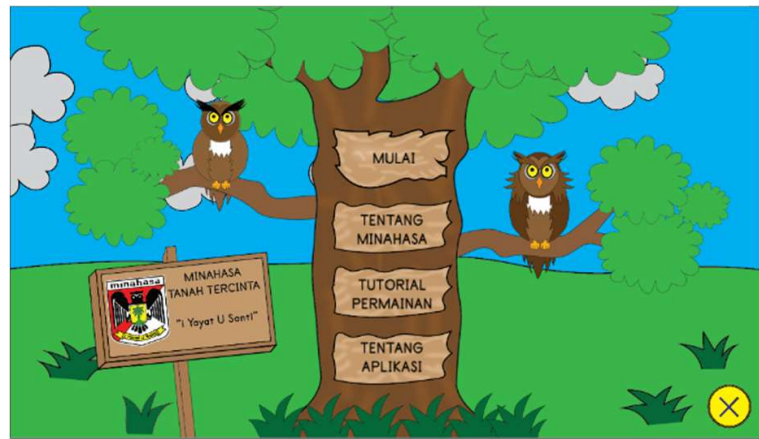

Gambar 6. Menu Utama

Tampilan Pada gambar 6, merupakan tampilan menu utama dari permainan Word Game Scramble Untuk Pengenalan Budaya Minahasa. Pada menu utama terdapat 4 tombol yaitu tombol mulai, tentang minahasa, tutorial permainan, tentang dan keluar. Jika menekan tombol Mulai, maka akan masuk dalam Scene pilihan permainan setelah itu akan masuk dalam permainan. Jika menekan tombol Tentang minahasa maka pemain akan melihat tentang sejarah minahasa dan beberapa informasi lainnya tentang minahasa. Jika menekan tombol Tutorial Permainan maka pemain akan melihat tutorial cara untuk bermain. Jika Menekan tombol Tentang Aplikasi, pemain akan melihat informasi tentang developer atau pengembang Word Game Scramble untuk pengenalan budaya minahasa, dimana terdapat didalamnya nama mahasiswa pengembang game dan nama Dosen Pembimbing Satu dan Dosen Pembimbing Dua.

\section{Tutorial}

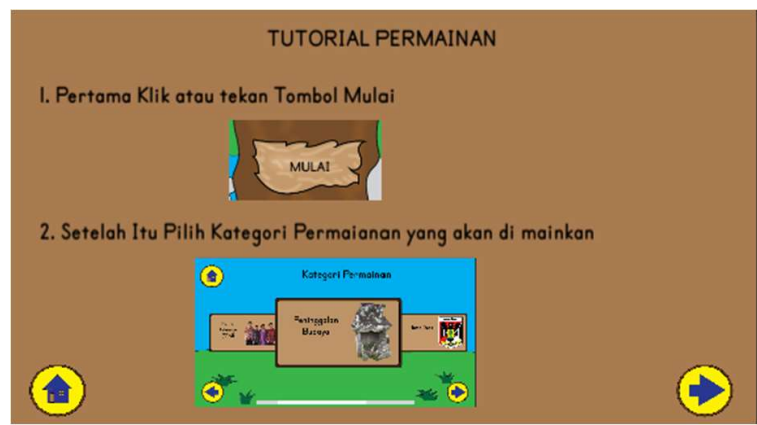

Gambar 7.Tutorial

Tampilan pada gambar 7, merupakan tampilan dari Scene Tutorial Permainan. Dalam Scene ini memberikan informasi tentang cara bermain dalam permainan Word Game Scramble ini.

\section{Tentang Permainan}

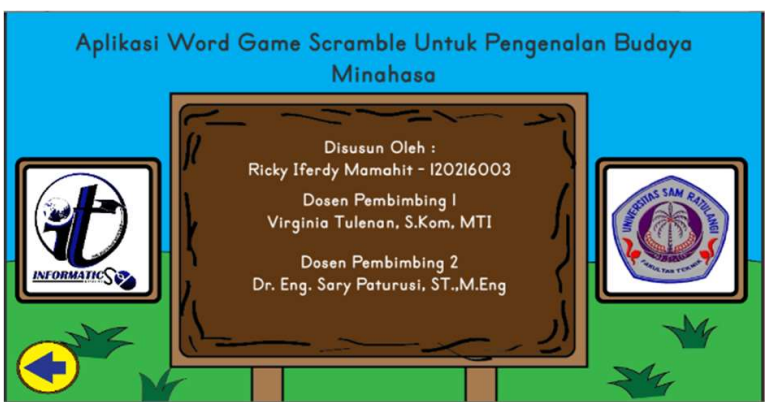

Gambar 8. Tentang Permainan

Gambar 8. merupakan tampilan dari Scene Tentang. Dalam Scene ini memberikan informasi tentang developer atau pengembang Word Game Scramble untuk pengenalan budaya minahasa, dimana terdapat didalamnya nama mahasiswa pengembang game dan nama Dosen Pembimbing Satu dan Dosen Pembimbing Dua.

\section{Kategori Permainan}

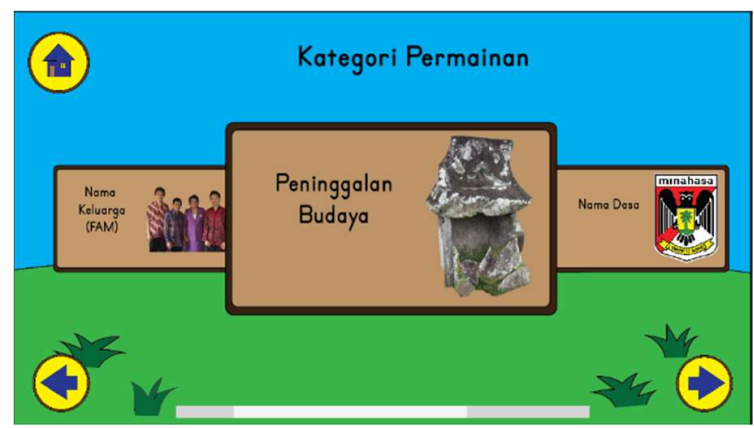

Gambar 9. Kategori Permainan

Tampilan pada gambar 9 Ketika Pemain menekan tombol mulai, makan Scene akan menampilkan kategori 
permainan yang akan dipilih. Pada Scene ini, terdapat 4 pilihan yaitu Nama Keluarga (FAM), Peninggalan Budaya, Seni Musik \& Seni Tari, dan Arti Nama desa.

6. Tampilan Permainan Kategori Seni Musik dan Seni Tari

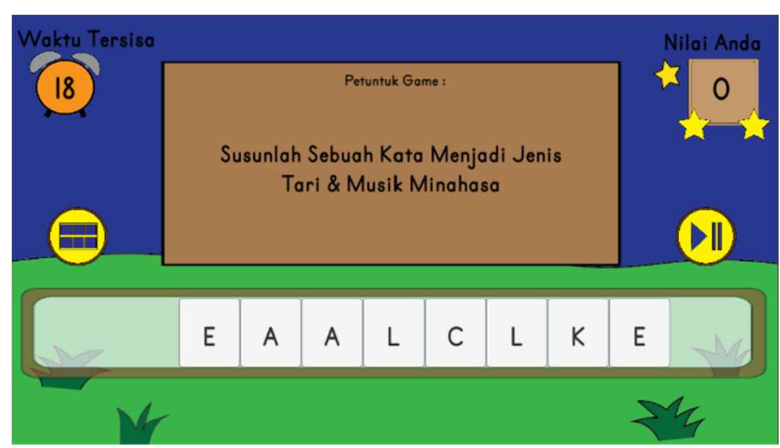

Gambar 10 Tampilan Permainan Kategori Seni Musik dan Seni Tari

Tampilan Gambar 10 merupakan tampilan dari permaianan Word Game Scramble dengan salah satu kategori permainan Seni Tari dan Seni Musik. Dalam Scene ini terdapat tombol kembali ke Scene kategori permainan dan Jeda.

\section{Tampilan Permainan Kategori Marga}

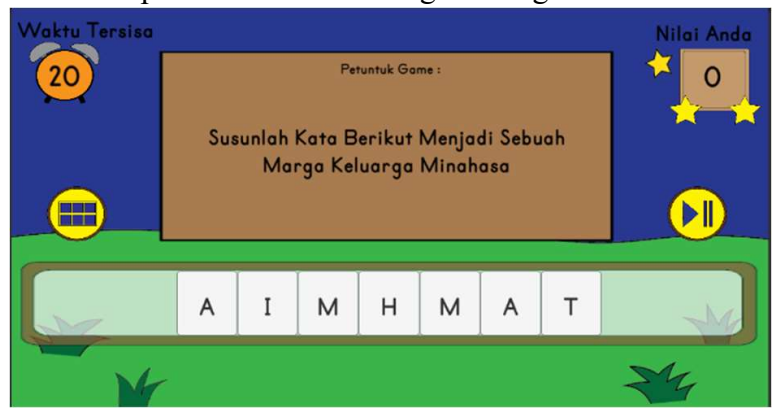

Gambar 11. Tampilan Permainan Kategori Marga

$$
\text { Minahasa }
$$

Gambar 11 merupakan tampilan dari permaianan Word Game Scramble dengan salah satu kategori permainan Marga Minahasa.

8. Tampilan Permainan Kategori Peninggalan Budaya

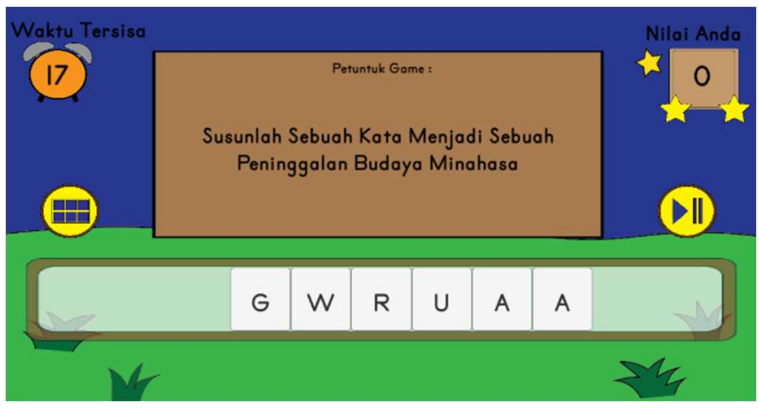

Gambar 12. Tampilan Permainan Kategori Marga Minahasa

Pada Gambar 12 merupakan tampilan dari permaianan Word Game Scramble dengan salah satu kategori permainan Peninggalan Budaya Minahasa.

9. Tampilan Permainan Kategori Arti Nama Desa

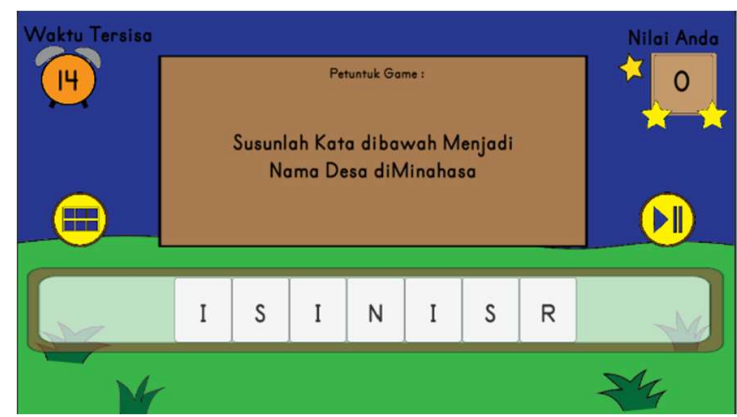

Gambar 13. Tampilan Permainan Kategori Nama Desa

Pada Gambar 13 merupakan tampilan dari permaianan Word Game Scramble dengan salah satu kategori permainan Arti Nama Desa Minahasa. Dalam Kategori ini, Dengan menyusun kata dengan memindahkan posisi karakter huruf ketempat yang benar maka akan tersusun sebuah kata yang benar.

\section{Tampilan Hasil dari Permainan}

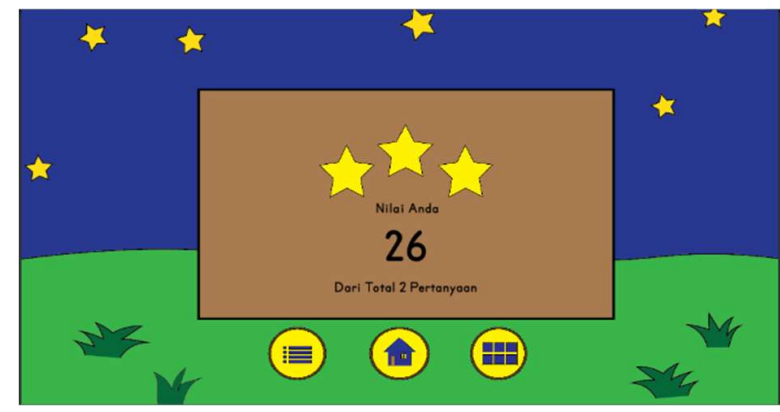

Gambar 14. Tampilan Hasil dari Permainan

Pada Gambar 14 merupakan tampilan dari hasil permainan setelah menyelesaikan satu kategori permianan maka tampilan ini akan muncul. Dalam Scene ini, terdapat 3 bintang yang muncul bersama dengan nilai yang pemain dapatkan saat bermain dan 3 tombol. Tombol pertama untuk melihat hasil permainan, kedua untuk kembali ke menu utama dan ketiga untuk kembali ke menu kategori game.

\section{B. Evaluasi Pengguna}

Evaluasi Pengguna game Word Game Scramble Of Mimahasa, dilakukan kepada 30 responden. berisikan 4 pertanyaan kepada 30 responden yang telah memainkan Word Game Scramble Of Minahasa.

1. Apakah game "Word Game Scramble Of Minahasa" mudah untuk dimainkan? 
Tabel 1. Hasil Evaluasi Pengguna terhadap tingkat kesulitan permainan

\begin{tabular}{|c|c|}
\hline & Jumlah Respoden \\
\hline Sangat Mudah & 25 orang \\
\hline Mudah & 5 orang \\
\hline Sangat Sulit & - \\
\hline Sulit & - \\
\hline
\end{tabular}

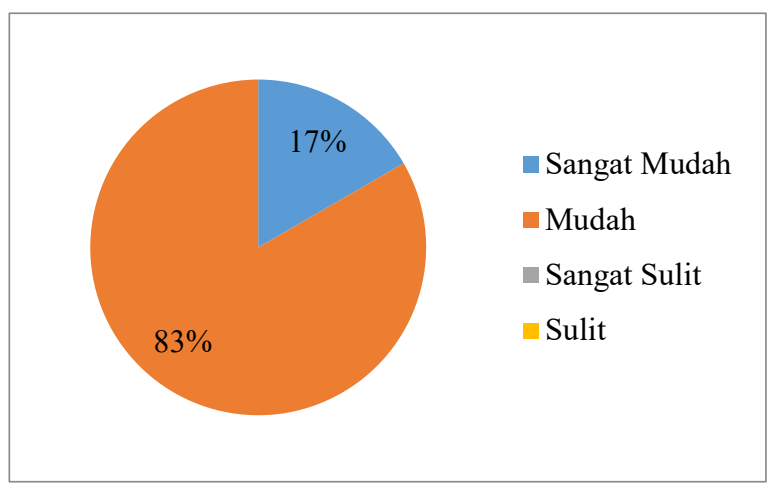

Gambar 14. Hasil Evaluasi Pengguna terhadap tingkat kesulitan permainan

2. Apakah anda terhibur dengan memainkan game “Word Game Scramble Of Minahasa”?

Tabel 2. Hasil Evaluasi Pengguna terhadap tingkat kepuasan

\begin{tabular}{|c|c|}
\hline \multicolumn{2}{|c|}{ kepuasan } \\
\hline Sangat Terhibur & 11 orang \\
\hline Terhibur & 17 orang \\
\hline Cukup Terhibur & 2 orang \\
\hline Kurang Terhibur & - \\
\hline
\end{tabular}

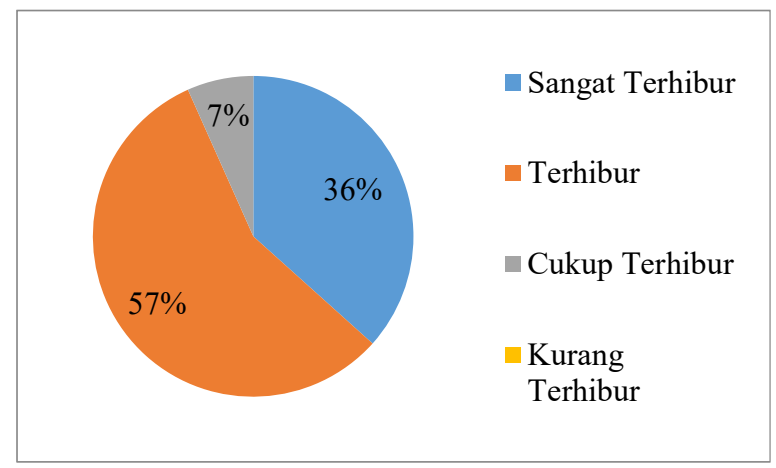

Gambar 15. Hasil Evaluasi Pengguna terhadap tingkat kepuasan

Berdasarkan hasil kuesioner tersebut didapat disimpulkan bahwa persentas responden terhibur ada $57 \%$ dan sangat terhibur ada $36 \%$.
3. Menurut anda bagaimana tampilan pada game "Word Game Scramble Of Minahasa"?

Tabel 3. Hasil Evaluasi Pengguna terhadap tampilan game

\begin{tabular}{|c|c|}
\hline & Jumlah Responden \\
\hline Sangat Bagus & 18 orang \\
\hline Bagus & 10 orang \\
\hline Cukup Bagus & 2 orang \\
\hline Kurang Bagus & - \\
\hline
\end{tabular}

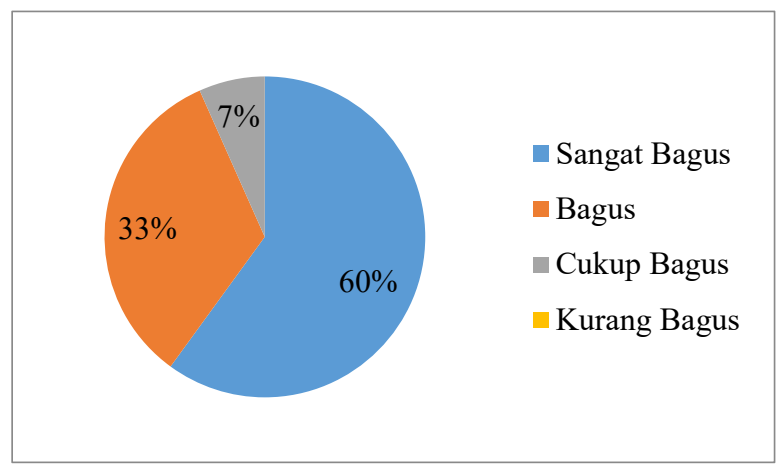

Gambar 16. Hasil Evaluasi Pengguna terhadap tampilan game

Berdasarkan hasil kuesioner tersebut didapat bahwa responden mengisi penampilan dari Word Game Scramble ini sangat bagus dengan presentase $60 \%$ atau sebanyak 18 orang dan Bagus dengan presentase $33 \%$ atau sebanyak 10 orang.

4. Apakah anda mendapat Informasi \& pengetahuan baru tentang Budaya Minahasa dengan memainkan game "Word Game Scramble Of Minahasa"?

Tabel 4. Hasil Evaluasi Pengguna terhadap Informasi dan pengetahuan yang didapat

\begin{tabular}{|c|c|}
\hline & Jumlah Responden \\
\hline Ya & 30 \\
\hline Tidak & - \\
\hline
\end{tabular}

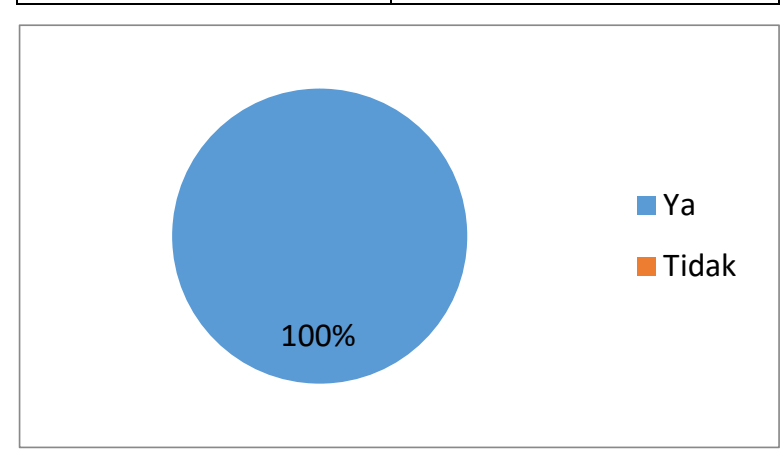

Gambar 17. Hasil Evaluasi Pengguna terhadap Informasi dan pengetahuan yang didapat 
Berdasarkan hasil kuesioner tersebut didapat bahwa responden mengisi Informasi dan pengetahuan yang didapat dari Word Game Scramble ini sangat bagus dengan presentase $100 \%$ atau 30 orang.

\section{PENUTUP}

\section{A. KESIMPULAN}

Dari Penelitian yang dilakukan diperoleh kesimpulan:

1. Aplikasi Word Game Scramble Pengenalan Budaya Minahasa telah selesai dibuat.

2. Aplikasi Word Game Scramble Pengenalan Budaya Minahasa memiliki 4 kategori permainan yang dapat dimainkan.

3. Aplikasi Word Game Scramble Pengenalan Budaya Minahasa ini ditujukan untuk semua umur.

4. Aplikasi Word Game Scramble Pengenalan Budaya Minahasa menjadi sarana untuk memperkenalkan Budaya Minahasa kepada masyarakat dengan cara yang interaktif dan menarik.

\section{B. SARAN}

Setelah dilakukan penelitian ini, Disarankan :

1. Database dalam game dapat ditambahkan lagi agar lebih menarik.

2. Desain Gambar lebih dibuat menarik lagi.

3. Game dapat dikembangkan dan atau dimodifikasi agar bisa dimainkan di perangkat PC dan IOS.

\section{DAFTAR PUSTAKA}

[1] Adhika Novandya, dkk (2012)."Aplikasi Pengenalan Budaya Dari 33 Provinsi Di Indonesia Berbasis Android." ProSiding Seminar Ilmiah Nasional Komputer dan Sistem Intelijen, Universitas Guna Darma Depok.

[2] Boy E.L. Rondonuwu (1984). “ Minahasa Tanah Tercinta."

[3] Ernest Adams (2010). "Fundamentals of Game Design"

[4] Haryadi. 2010. "Analisis dan Desain Aplikasi Berbasis Multimedia sebagai Sarana Informasi dan Promosi pada Teater Manggar". STIMIK AMIKOM. Yogyakarta

[5] KlikPengertian, Pengertian UML Beserta Contohnya, http://www.klikpengertian.com/2017/01/pengerti an-uml-unified-modeling-language-besertacontohnya.html, waktu diakses : 1/5/2017 12:22 PM

[6] Magdalena J.Sumarauw (2013).’Tari Maengket”. Kepel Press.Yogyakarta.
[7] Maria E. Tangkilisan (2013)."Tari Kabasaran”. Kepel Press.Yogyakarta.

[8] Riyadi A. 2013. "Perancangan Game Motorace untuk Android Mobile". STMIK AMIKOM. Yogyakarta

[9] Roger S. Pressman,Ph.D, "Rekayasa Perangkat Lunak", $7^{\text {th }}$ ed., Yogyakarta : ANDI, 2012.

[10] Steven Sumolang, 2012. Pergelaran Budaya Sulut dan TIFF 2012. Tabea. Edisi 5.ISSN : 2087-6424. 31-34.

[11] Steven Sumolang, 2013. Pergelaran Budaya Sulawesi Utara. Tabea. Edisi 6.ISSN : 2087-6424. 17-19.

[12] Tay Vaughn (2010). "Multimedia: Making It Work Eighth Edition"

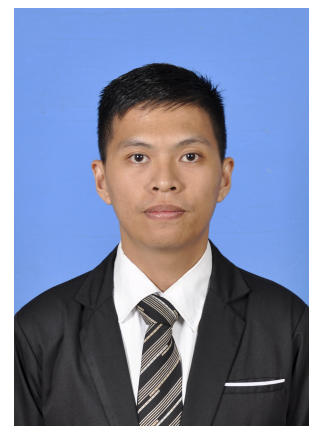

Sekilas Tentang Penulis dengan Nama lengkap Ricky Iferdy Mamahit, anak 3 dari tiga bersaudara. Lahir di Mogolaing, Kota Kotamobagu, Sulawesi Utara pada tanggal 7 Juli 1994. Dengan alamat tempat tinggal sekarang di Kotobangon Atas, Kota kotamobagu. Saya mulai menempuh pendidikan di sekolah dasar Negeri 1 Kotobangon (2000 - 2006). Setelah itu saya melanjutkan pendidikan tingkat pertama di SMP Kristen Kotamobagu (20062009).Selanjutnya saya menempuh pendidikan $\mathrm{Ke}$ Sekolah Tingkat Atas, di SMA Kristen Kotamobagu (2009 - 2012). Setelah itu, di Tahun 2012 saya melanjukan pendidikan ke salah satu perguruan tinggi yang berada di Manado yaitu Universitas Sam Ratulangi Manado, dengan mengambil Program Studi S-1 Teknik Informatika di Jurusan Elektro, Fakultas Teknik. Penulis membuat Skripsi demi memenuhi syarat memperoleh gelar Sarjana (S1) dengan penelitian berjudul Rancang Bangun aplikasi Word Game Scramble Untuk Pengenalan Budaya Minahasa yang dibimbing oleh dua dosen pembimbing yaitu Virginia Tulenan, S.Kom.,MTI dan Dr. Eng. Sary D. E. Paturusi, ST.,M.Eng serta pada tanggal 12 Juni 2017 penulis resmi lulus dari Program Studi Teknik Informatika Jurusan Elektro Fakultas Teknik Universitas Sam Ratulangi Manado dan menyandang gelar Sarjana Komputer. 